\title{
The Continuity of Action and Thinking in Learning:
}

\author{
Re-visiting John Dewey
}

\begin{abstract}
If we are willing to conceive education as the process of forming fundamental dispositions, intellectual and emotional, toward nature and fellow men, philosophy may even be defined as the general theory of education.
\end{abstract}

(Dewey 1916, c. 1966: 328).

\begin{abstract}
:
In recent years, there have been many attempts at defining learning as a social phenomenon as opposed to an individual and primarily psychological matter. The move towards understanding learning as social processes has also altered the concept of knowledge as a well-defined element stored in books, brains, CD-Roms, disks, videos or on the Internet. Instead, knowledge has been perceived as a social and context related construction. The roots of the social angle within theories on learning and knowledge are much older than the current literature suggests. This paper illustrates how these theories can be traced back to pragmatism as a philosophy and foundation for an educational approach introduced by the American, John Dewey, more than one hundred years ago. The paper also suggests that Dewey avoids some pitfalls that have come with the new theories, particularly the strong division between individual vs. social and school vs. everyday life learning.
\end{abstract}

\section{Introduction}

I n recent years, several researchers have contested the validity of the cognitively inspired learning theory focusing on individuals (Brown, Collins \& Duguid 1989; Lave 1988; Salomon 1993). The view of learning as an activity defined in time and space, comprising communication, transfer and acquisition of knowledge at certain times in life, has been challenged. The view that learning happens only limited to specific spaces and occasions, such as receiving training or attending a course, reading a book, working with a CD-Rom, on the Internet or with an instruction video, has been shown to be too limited. The new social learning theories point to problems in understanding learning as an individual, cognitive and delimited activity.

Instead, the new learning theories emphasize that learning takes place when we participate in - and across - communities of 
practice (Dreier 1999; Lave \& Wenger 1991; Wenger 1998; Østerlund 1996). Learning takes place by participating in and reflecting on actions performed in socially well organized settings, e.g., in some kind of apprentice situation (Nielsen \& Kvale 1999; Schön 1983, 1987). Learning is a collective phenomenon derived from actions and practice - and not primarily from the universe of thought. In other words, learning is a lifelong project that goes on everywhere all the time. According to the new social learning theories, knowledge is constructed in communities of practice as a result of concerted actions across persons. In this approach, learning and research on learning enter the social and sociological field, stepping out of the individual-oriented psychological sphere.

Although it has been liberating to add social considerations to the usual focus on individual learning, some versions of situated learning have allowed social to stand in too stark contrast to individual as if they were a natural and essential dualism. Instead, I suggest to view learning as both a deeply individual and a collective phenomenon, and to see learning as involving both action and thinking, body and head, non-discursive and language experiences. This view is inspired by the American pragmatist and educational thinker, John Dewey (1859-1952), who developed a coherent concept of knowledge and learning by virtue of his concept of experience. ${ }^{1}$

For sixty years, Dewey tried to reunite action and thinking, the non-discursive and

1 In recent years, there has been a renewed interest in Dewey - and pragmatism - from several quarters. It is first and foremost due to Richard Rorty (1979, c. 1980, 1982) that pragmatism has been rediscovered as philosophy, although his interpretation of Dewey's pragmatism has provoked much criticism (see e.g., Stuhr 1993). In Denmark, Dewey's name is sometimes mentioned in passing in connection with various writings on education and pedagogy. The comments are rarely positive and of- the linguistic, and the physical and the cognitive aspects of human experience as well as learning in schools and in everyday life. Of course, his thinking went through changes, just as his life bore the marks of shifts and changes. We must begin, therefore, with a small account of Dewey's life. For readers interested in knowing more about his life there are many sources, some of which are mentioned below. The remains of the paper focus on the philosophical issues. Opinions vary on how to sequence Dewey's philosophical and educational thinking, because they are so closely related. I have chosen to start with his philosophical anchorage, namely, pragmatism, and to develop secondly his educational thinking focused on two central concepts, namely, experience and inquiry.

\section{Dewey - life and work}

Tohn Dewey lived a long and eventful life and almost reached the age of 93 .

- He was born into a middle-class family on October 20, 1859, in Burlington, Vermont, as the third of four sons. In 1879, Dewey graduated from the University in Vermont after which he taught at a high school for a couple of years, simultaneously taking private lessons in philosophy. Later, in 1882 , Dewey began to study philosophy at the newly established Johns Hopkins University in Baltimore, where he was introduced to Friedrich Hegel's (1770-1831) philosophy thanks to his teacher, George S. Morris.

ten superficial (Illeris, Laursen \& Simonsen 1978; Illeris 1999), although there are exceptions (e.g. Winther-Jensen 1998). Presumably, it is not due to the scarce number of Scandinavian translations of Dewey. Although only two of Dewey's books have been translated into Danish (Fink 1969), the interest in studying Dewey's philosophy and educational thoughts is much greater in Sweden and Norway (Lundgren 1989; Løvlie 1989). 
Dewey himself interprets his fascination of Hegel as a need to understand the world as a coherent whole rather than a place for "atomic individualism and sensationalistic empiricism" (Dewey 1930, here from Bernstein 1960: 9). Dewey also describes his attraction to Hegel's philosophy as a personal need he felt in his first years as a budding philosopher. Dewey writes:

[Hegel's thought] supplied a demand for unification that was doubtless an intense emotional craving, and yet was a hunger that only an intellectualised subject matter could satisfy. It is more than difficult, it is impossible, to recover that early mood. But the sense of divisions and separations that were, I suppose, borne in upon me as a consequence of a heritage of New England culture, divisions by way of isolation of self from world, of soul from body, of nature from God, brought a painful oppression - or, rather, they were an inward laceration. My earlier philosophic study had been an intellectual gymnastic. Hegel's synthesis of subject and object, matter and spirit, the divine and the human, was, however, no mere intellectual formula; it operated as an immense release, a liberation.

(Dewey 1930, here from Bernstein 1960: 10).

Here, in his only autobiographic work, Dewey looks back, at the age of 70, at how his thinking and life as a philosopher have developed - with all the rationalisations of the intervening years. With the wisdom of hindsight, Dewey understands that Hegel led him away from a philosophising primarily consisting of intellectual exercises to a way of thinking that also touched his emotional universe. Hegel brought clarity and order into Dewey's feelings - from "inward laceration" to an "immense release" - and not only to his intellect.

Hegel's understanding of the individual's connectedness to history, culture and environment appealed both intellectually and emotionally to Dewey. The conception of connection, continuity, and coherence fol- lowed Dewey all his life, although in another form than Hegel's. Later in life, Dewey was influenced by Darwin's evolutionary thinking and that time's functional, social-psychological understanding of the individual. This led him to see coherence as a synthesis between the human "existence" (Dewey's term) and its biological and social environments. In Dewey's conception, the coherence was taken from Hegel's "absolute spirit" and placed in the secular, human, physical, and social existence.

One of Dewey's students, Max Eastman (1945, c. 1959), indicates that before Dewey began studying philosophy at Johns Hopkins, he had a "mystic experience" by which he understood that the religious - or spiritual aspect was part of life itself and not something outside or above life. Dewey had this experience in Oil City, Pennsylvania, where he taught a high school. Eastman writes:

One evening while he sat reading he had what he called a "mystic experience." It was an answer to that question which still worried him: whether he really meant business when he prayed. It was not a very dramatic mystic experience. There was no vision, not even a definable emotion - just a supremely blissful feeling that his worries were over. Mystic experiences in general, Dewey explained, are purely emotional and cannot be conveyed in words. But when he tried to convey his in words, it came out like this: "What the hell are you worrying about, anyway? Everything that's here is here, and you can just lie back on it."

(Eastman 1945, c. 1959: 256-57).

The focus on Dewey's relationship to the religious and spiritual aspect must be seen in the context of the time (the end of nineteenth century), when it was mostly theologians and clergymen who occupied themselves with philosophy. Things were different at Johns Hopkins, where Dewey formally studied philosophy, but the entire philosophical milieu of the time was influenced by religious thought. 
Morris not only introduced Dewey to Hegel; he was also a source of inspiration for Dewey's later interest in logic. In the 1880's, Dewey and Morris developed an "intermediate kind of logic that was neither merely formal nor a logic of inherent 'truth' of the constitution of things; a logic of the processes by which knowledge is reached" (Jane Dewey 1939, c. 1951: 18). This is what Dewey and several Dewey researchers have called "the logic of experience", because the origin of knowledge is precisely living experience and not the other way around, as if logical theorems might govern thinking (McDermott 1973, c. 1981; Sleeper 1986).

Morris not only supported Dewey's emotional and intellectual development, but his personal life as well. In 1884, he was instrumental in getting Dewey a position at Michigan University in Ann Arbor, where he met his first wife, Alice Chipman (1859-1927). John and Alice were married in 1886 and had six children in addition to a child they adopted when one of their own children, Gordon, died at the age of eight. Dewey's wife is often given the credit for opening his philosophical interest from classical philosophy towards the social field and his lifelong interest in the "democratic project" (Jane Dewey op.cit.; Westbrook 1991).

Ten years later, in 1894, Dewey moved from Michigan to the newly established Chicago University, where he became head of the Department of Philosophy, which included psychology and pedagogy. This inter-disciplinary challenge was the major reason Dewey accepted a move from Ann Arbor in Michigan to the University of Chicago. It was here that John Dewey and his wife created a school, later known as the Laboratory School (Hendley 1986; Tanner 1997), where he tested his ideas on pedagogy. In 1904, the university leadership made some decisions about the future of the
Laboratory School without consulting Dewey. As a result, Dewey resigned immediately and took up a position as Professor in Philosophy at Columbia University in New York. Here, he stayed until he retired in 1930 , only interrupted by a number of travels to Japan, China, Turkey, Mexico and the Soviet Union. As a matter of curiosity, I mention only that Dewey in 1937 was chairman for a court of inquiry, the "Trotsky Hearings", that took place in Diego Rivera's house in Coyacan on the outskirts of Mexico City.

In 1927, Dewey's wife died at the age of 68 from arteriosclerosis. After 41 years of married life, which also included a work relationship, e.g. the Laboratory School, it was a great loss to Dewey. Dewey's children took care of him until 1946, when he married a forty-two-year old woman, Roberta Lowitz Grant. At that time, Dewey was 87 years old. John and Roberta adopted two Belgian children, a brother and a sister, John and Adrienne, who had been orphaned during the Second World War (Dykhuizen 1973). Shortly before his 92nd birthday in 1951, Dewey broke his hip while playing with John and Adrienne. He healed very slowly and was locked up in his apartment during the whole winter and the spring months of 1951-52. When the weather permitted, he was wheeled out in his wheelchair, but he never learned to walk again. On Saturday, May 31, Dewey had another attack of pneumonia and died at 7 a.m. on June 11952 in his apartment on 5th Avenue in New York City.

\section{Pragmatism}

$\mathrm{F}$ or Dewey, philosophy was closely related to educational thinking - or learning, which I assume is the concept Dewey would have used today. The relationship between a philosophy comprising 
a certain view of real life, a corresponding concept of knowledge and an understanding of human action constitutes the basis for a "general theory on education" (Dewey 1916, c. 1966: 328). Conversely, if the theory on education does not build on a coherent understanding of reality, knowledge and human action, there is a risk that the pedagogic will turn into barren principles and techniques.

Dewey's philosophical - and thus his pedagogical - point of departure is the living experience of everyday life. According to Dewey, philosophy is to be understood in terms of the problems with which it deals, and these problems originate in the conflicts and difficulties of social life.

The problems are such things as the relations of mind and matter; body and soul; humanity and physical nature; the individual and the social; theory - or knowing, and practice - or doing.

(Dewey 1916, c. 1966: 324).

It is on this foundation that Dewey's version of pragmatism builds and develops a philosophical system. When we use the term "pragmatic" in our everyday speech about a person's actions, it implies that he or she acts from a results oriented, non-ideological basis. In popular speech version of pragmatic, neither the reasoned value nor the moral worth of an activity is important as long as the intended results can be achieved. In relation to the philosophical meaning of pragmatism, this is a distorting and ironic simplification. Even in philosophical circles, the meaning of pragmatism is not unambiguous.

Pragmatism has had several architects over the years, and there have been many interpreters (see e.g. Bernstein 1960; Childs 1956; Dworkin 1959; Garforth 1966; Haskins \& Seiple 1999; Rorty op. cit.; Scheffler 1974, c. 1986; Sleeper 1986). The early pragmatists were Charles S. Peirce (1839-
1914), William James (1842-1910), George H. Mead (1863-1931) and then John Dewey. Dewey is the pragmatist who has been given credit for linking pragmatism to actual educational thinking. He used pragmatism to prescribe and practice measures of content and pedagogical initiatives in the school system (Dewey 1916, c. 1966). Often, Dewey employs the concepts "instrumentalism" and "experimentalism" to describe his version of pragmatism (Dewey 1931, here from McDermott 1973, c. 1981, Dewey 1933, c. 1986). An important feature in pragmatism is that ideas, theories and concepts - i.e. different forms of thinking and abstraction function as instruments for actions.

$$
\begin{aligned}
& \text { (...) thinking is a process of inquiry, of looking } \\
& \text { into things, of investigating. Acquiring is always } \\
& \text { secondary, and instrumental to the act of inquiry. } \\
& \text { It is seeking, a quest, for something that is not at } \\
& \text { hand. }
\end{aligned}
$$

(Dewey 1916, c. 1966: 148).

Thinking functions to generate working hypotheses, the consequences of which are tested in actions that therefore can be seen as experimental. Experimental actions based on the concept of knowledge in pragmatism are not merely examples of "trial-and-error" actions. They are actions governed by an idea or a hypothesis. The nature of actions is always delimited or selective, because we cannot act in general, nor in a vacuum. The essence of action is irremediably contextual. It follows that thinking and ideas or meanings developed through thinking are contextual as well. Thus, a reflected action is created in relation to a specific situation or problem. This interconnectedness between thinking and action is also evident in Dewey's concept of experience and in his concept of inquiry.

Pragmatism is a philosophy clearly rooted in the everyday life of the turn of the century America (from the nineteenth to the 
twentieth century). At the same time, pragmatism also springs from European philosophy and the scientific developments of the time - especially within biology (the theory of evolution) and psychology (functionalism). At the turn of the century, the USA still showed traces of being the "new" world to which many people emigrated out of necessity or love of adventure. The emigrants started on a new life in the new country; they had left behind European class-divided societies based on traditions and family relations.

The new - and also slightly older - Americans were oriented towards the future. They lived in a country where the western frontiers were still open and alluring. At the time, the USA was a country where industrialisation and mass production slowly were affecting the development of society. The turn of the century was a time marked by changes and insecurities. Rhetorically anyway, people had to prove their worth by their own actions and values instead of being born into a more or less privileged family. Above all, at this time, the USA showed signs of optimism and belief in progress and development (Childs op. cit.; Scheffler op. cit.).

Similarly, the development of pragmatism should also be seen in continuation of - and as a reconstruction of - the European history of philosophy. ${ }^{2}$ As the first of the architects of American pragmatism who used the term pragmatism, Peirce is indebted to the German philosopher Immanuel Kant (17241804). In his writings, Kant had made a distinction between the concepts "pragmatic"

2 One of Dewey's books is called Reconstruction in Philosophy (1920, c. 1936). The book is based on Dewey's lectures at the Imperial University in Tokyo in 1919. It is also one of the two books that has been translated into Danish by Hans Fink (op. cit.). The other book is a translation of the diminuitive Experience and Education (1938, c. 1963). and "practical". Kant used the term "practical" to describe rules and concepts within the realm of moral philosophy, where it is possible to acquire knowledge a priori that is, without reference to human experience. According to Kant, inquiry into the a priori offers a method to establish transcendental and logical truths. Kant applied the term "pragmatic", to the fields of art and technique as these areas stem from human experience and should be regarded as a posteriori. They comprise knowledge that refers directly to human experience.

The pragmatists shared a view of human existence as being continuously formed and forming itself and its surroundings. This is why we talk of action as transactional instead of just interactional. ${ }^{3}$ Contrary to other living beings, humans can use their ability to act more and more informed - or "intelligent" which was the word Dewey used - in an effort to improve their surroundings. Dewey's use of the term intelligence must not be confused with today's use of the concept, which often gives associations to intelligence tests and differences in intelligence as something hereditary and natural. De-

3 Late in life, Dewey characterized what he had previously called interaction as transaction. In his latest book, Knowing and the Known (1949, c. 1991 with Arthur F. Bentley), he writes the following about transaction: "The knowing-known taken as one process in cases in which in older discussions the knowings and knowns are separated and viewed as in interaction." (op. cit.: 272). Further, definitions from Oxford Dictionary are cited: "Transactions: doings, proceedings, dealings. Interaction: reciprocal action or influence of persons or things on each other." (op. cit.: 265). In 1960, Bernstein writes the following about Dewey's shift from applying interaction to transaction: "Transaction is a refinement of interaction. In a transaction, the components themselves are subject to change. Their character affects and is affected by the transaction. Properly speaking, they are not independent: they are phases in a unified transaction. Thus transaction is a more rigorous formulation of the category of the organic which is embedded in Dewey's earliest philosophic writings. Transaction is a generic trait of existence." (Bernstein op.cit.: xl). 
outlines-2000. qxd 23-11-00 12:55 Side 91

wey's concept of intelligence reflects that human beings can consciously use their experience, their knowledge, to form themselves and their surroundings.

The pragmatic reconstruction of the knowledge concept from resting partly on a priori theorems to resting fully on human experience did not interest Dewey if the reconstruction could not be used to change and improve people's intellectual and moral orientation. Thus, pragmatism is also, indeed primarily, a method by virtue of its concept of inquiry. It is a means to solve problems and improve the world. According to the pragmatists, and especially to Dewey, the hope of a better world rests on people's efforts to construct a world in which productive reflection becomes possible. According to Dewey, it means to reason intelligently and subsequently to act intelligently. This is the way we learn, and therefore the exercise in using thinking as an instrument in experimental action is the core in Dewey's educational thinking.

\section{Educational thinking}

A s mentioned before, Dewey considered philosophy to be "the general theory on education". In continuation of this view, Dewey looked at education as "the laboratory in which philosophic distinctions become concrete and are tested" (Dewey 1916, c. 1966: 329). According to Dewey, philosophy has the practical function, because it can direct the formation of new experiences through a stringent inquiry into the past and present. Dewey did not claim that methods from natural science could be applied directly to human affairs, but that "intelligent action" or a "scientific attitude" ought to be part of all human life. The scientific attitude implies a willingness to engage in inquiry in order to solve an uncertain situation. Education is the means to examine previous experiences and reflect on the relevance of their values (Dewey 1916, c. 1966: 328).

Dewey applied the ideas of functional psychology and his instrumentalist theory of knowledge to his theories on education. These theories Dewey tested in his Laboratory School during the eight years he was the head of the school. According to functional psychology, life and learning are social phenomena. The intellect is viewed as a function of social life and cannot function in isolation or develop by itself. To allow an intellect to develop requires continuous stimulation from the surroundings. In the process, human experience is developed and improved. The sociality of learning and education thus pervades Dewey's thinking. Separated from each other, the individual and society are merely abstractions. Actual learning regardless of whether in the form of education or life as a whole takes place in the transaction between the individual and his/ her surroundings.

Dewey strongly rejected the idea that education is merely "preparation". Of course, we might say that Dewey's instrumentalism is preparation for the future, but this meaning differs from what we normally understand by education as preparations, namely, preparations for another education, a job, etc. For Dewey, education - or learning - is a reconstruction of experience, it is a continuous unfolding of potential where each step is a "preparation" for the next. For pragmatism, unlike the way most educational theorists like to think and most schools operate, the future goals of unfolding experience are never known in advance - at least not in their final form, because they are approached experimentally and formed by testing the consequences.

Dewey attacks every attempt at educating for performance objectives determined in advance and out of context, e.g. by imagin- 
ing the conditions under which the new experiences will be used. If education is planned in such a way, it implies that the skills achieved at one time can be transferred efficiently and applied at a later time and under quite different conditions. Long in anticipation of the new social learning theories, Dewey claimed that an automatic transfer of learning does not exist. Rather, education should be based on experiences that the learning individuals already have and intend to develop further. Dewey considered it contradictory to apply the present as a means to prepare for the future. We can only prepare for the future by trying to understand the time in which we play a part:

We always live at the time we live and not at some other time, and only by extracting at each present time the full meaning of each present experience are we prepared for doing the same thing in the future. This is the only preparation which in the long run amounts to anything.

(Dewey 1938, c. 1963: 49).

Dewey criticises not only the established educational system, but also the different forms of progressivism within educational thinking and pedagogy, with which he has sometimes been identified (see e.g. Illeris, Laursen, Simonsen op. cit.). It is important to point out that Dewey repeatedly rejected any association to the "Progressive Education Association" (PEA) established in 1919 , although in 1928 , he consented to become honorary president of the organisation. He used the occasion to underline the necessity of intellectual rigor in the reformation of the educational system, advocated by the progressive educational thinkers, if the movement wanted to be taken seriously. Unfortunately, Dewey's warnings had little effect on those who called themselves his successors.

As a social movement, progressivism elevated the individual's present experience over humanity's collective historical experiences, and it never gave a positive formulation of the role of cummulative knowledge and authority in human affairs. Progressivism was not sufficiently aware of the dangers built into their concept of freedom, which could easily be misinterpreted as laissez-faire pedagogy. In other words, it placed too much emphasis on the individual child's present needs and impulses at the expense of the collective and historically determined experiences (Dewey 1938, c. 1963). This one-sided focus on the learning subject without any thought for the content of the learning process and its use in the social world conflicted with Dewey's ideas about people using their individual and collective experiences to act progressively more informed and intelligent.

\section{The concept of experience}

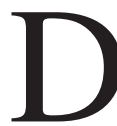
ewey emphasised the experimental nature of the concept of experience, and the relation of experience to reason, emotion, and the organization of a future. ${ }^{4}$ For Dewey, experience deals with transactions between a living person and its physical and social surroundings. By surroundings, Dewey does not mean a nature separate from human activity, nor is activity isolated from its situation in the world. Surroundings are experiences, and experiences are achieved reflexively in transaction with the surroundings. In other words, experience is simultaneously a product, a content and a process, a method.

4 Dewey developed his concept of experience practically all his life. This paper is based on Dewey's development from the essay The Postulate of Immediate Empiricism $(1905$, c. 1981) to his work with the concept reflective experience in the book Democracy and Education (1916, c. 1966). Other important books about his concept of experience are Experience and Nature (1925, c. 1958) and Art as Experience (1934, c. 1958). 
outlines-2000.qxd 23-11-00 12:55 side 93

$[\ldots]$ experience is of as well as in nature. It is not experience which is experienced, but nature stones, plants, animals, diseases, health, temperature, electricity, and so on. Things interacting in certain ways are experience; they are what is experienced. Linked in certain other ways with another natural object - the human organism they are how things are experienced as well Experiences thus reaches down into nature; it has depth. It also has breadth and to an indefinitely elastic extent. It stretches. That stretch constitutes inference.

(Dewey 1925, c. 1958: 4a).

The scene, the setting, the situation, the context, the transaction, all refer to the mutual formation of humans at work with their surroundings. The surroundings live their own life; they are subject to their own relations, which of course we experience. But the mutual formation of human activities and their surroundings also goes beyond the given surroundings. The crux of the human situation is that we can inquire into and transform how we experience and what we experience. For Dewey, life itself means to be involved in the transactions that constitute experience. Experience is a life process that continuously moves, as new problems are an incentive to intelligent - i.e., reflective - actions and thus new experiences. Education in the sense of "schooling" is a specialised form of experience that aims to govern the process, to make it more profitable than if the individual had been left on his/her own.

Content is inseparable from method. As experience is transactional, intelligent action is governed by the action's aim. Transaction is a refinement of the concept "interaction". In a transaction, the components themselves are subject to change. Their nature affects and is affected by the transaction. More precisely, they are not independent - they are phases in a united transaction. Transaction is a common feature in our existence. There is no gap between them. Method is simply the intellect's efforts to work with the content of experience regardless of whether it is provided by the school system or by chance through life in general. It follows that we should think less of teaching methods than of methods for learning and experience.

In the first place, experience involves the principle of continuity (Dewey 1938, c. 1963). It implies that all present experiences grow out of past experiences, which in turn leads to future experiences. We do not enter an educational or learning process as a blank page. We have experiences we bring with us into the learning process. Secondly, the principle of interaction is involved. ${ }^{5}$ It means that experiences are created in the interaction between individual qualifications and social conditions. Expressed differently, the learning process deals with the relation between the individual and the surroundings. Learning - development and change of human beings - takes place in the transaction between the individual and the situations that he/she is part of. It is through this transaction that experiences are created.

The provocative element in experience, i.e. the element that arouses the intelligence and puts it to work, is to face an uncertain or problematic situation. When habitual actions are upset, it creates the basis for gaining new experiences. The difficulties and problems must originate in the learning subject's previous experiences. They must not be forced upon her from the outside, and they should be within her capacity of solving problems. As a result of inquiries into problematic situations, we gain new experiences. We construct new knowledge, that depends partly on our ability to reflect on the relation between our actions and their consequences, partly on the relations we can establish to our previous experiences. How-

\footnotetext{
5 Dewey was still using the concept of "interaction" in 1938.
} 
ever, some experiences may not be apprehended as such, i.e. they do not enter our conscious and verbal sphere. Dewey talks a great deal about the aesthetics of experiences and the sensation that they perfect or complete - at least for a time. Any delight and comfort in a situation is also an experience (McDermott op. cit.). There is little distinction between an intellect that knows and a body that acts. Along the continuum of experience, there is a vague transfer between non-cognitive and cognitive experiences that is crucial to learning. If we want to learn from our experiences, we must get them out of the physical and non-discursive field and turn them into acknowledged and conscious experiences.

To "learn from experience" is to make a backward and forward connection between what we do to things and what we enjoy or suffer from things in consequence. Under such conditions, doing becomes a trying; an experiment with the world to find out what it is like; the undergoing becomes instruction - discovery of the connection of things. Two conclusions important for education follow. (1) Experience is primarily an active-passive affair; it is not primarily cognitive. But (2) the measure of the value of an experience lies in the perception of relationships or continuities to which it leads up. It includes cognition in the degree in which it is cumulative or amounts to something, or has meaning.

(Dewey 1916, c. 1966: 140).

We gain our experiences as a result of how we live our lives and how we associate with other people. This, in turn, depends on who we are as persons and how we enter into these relations, but it is difficult to avoid gaining any experiences. But if we are going to learn from our experiences, we have to use our ability not only to contemplate the relation between our actions and their consequences, but also to relate them to our present experiences. Only at this point do our experiences turn into reflective experiences
- learning experiences. It is in our efforts to become aware of our experiences that we can use them to act in a more intelligent and future-oriented manner, and it is here that education comes into the picture. A teacher or a more experienced person can help the learning subject in his/her efforts to reflect consciously.

Dewey emphasises the continuity between immediate, non-discursive experience and people's cognitive and intellectual experience. He stresses the cognitive role of non-discursive experience, just as thinking - or consciousness - may be used to change, e.g., bad physical habits (Shusterman 1994, c. 1999). ${ }^{6}$ We reflect all the time when we evaluate, oppose, search and find - such activities are not reserved for special situations. We are changeable creatures and creatures with a conscious capacity to experience. An experience may function as a drama or a narrative: "I dare say that was an experience!" It takes us beyond our normal state of consciousness.

\section{Inquiry}

$\mathrm{T}$ he concept of inquiry in pragmatism developed out of the criticism leveled at the concept of knowledge in formal logic with its references to a priori knowledge above and beyond the human world of experience. Early in his career, Dewey was looking for a logic closer to human experience:

\footnotetext{
6 Dewey was inspired by F. Matthias Alexander, the inventor of the "Alexander technique", a therapy in which an experienced teacher attempts to make people conscious of their bad physical habits by making them stand, walk, lie down, sit and get up in ways that are more suited for the human body. It is a method using consciousness to change physical habits. Dewey wrote the preface to several of Alexander's books, e.g. Alexander (1923, c. 1983).
} 
outlines-2000.qxd 23-11-00 12:55 Side 95

Any book of formal logic will tell us what this conception of thought is: thought is a faculty or an entity existing in the mind, apart from facts, having its own fixed forms, with which facts have nothing to do - except in so far as to pass under the yoke.

(Dewey 1891, c. 1969: 127).

In fact, Dewey completely rejected the concept of knowledge and chose to employ the term "warranted assertibilities" to indicate the contextual and continuous nature of knowledge (Dewey 1890A; 1890B, c. 1969; 1938, c. 1949: 7ff). Dewey argued that all logical forms originate in inquiry, which at the same time is a verification process for proper statements in a pragmatically defined knowledge (Dewey 1938, c. 1949: 3-4, see also Burke 1994). ${ }^{7}$

Dewey's development of logic as a theory of inquiry is based on our everyday life experiences. Inquiry cannot be reduced to a response to purely abstract thoughts as it is anchored in situations as part of our everyday life. It is part of life to inquire, turn things around intellectually, come to conclusions and make evaluations. We do it all the time whether we know it or not. This is how we learn and become cognizant human beings. According to Dewey, a theory on logic can only be relevant if it deals with the way in

7 Dewey's study of logic culminated in his book Logic: The Theory of Inquiry (1938, c. 1949). The book was published when Dewey was nearly 80 years old and is the result of a life's work. Dewey began his study of logic in 1890 by writing two articles "Is Logic a Dualistic Science?" and "The Logic of Verification" (1890A; 1890B, c. 1969). In an article written approximately ten years later "Some Stages of Logical Thought" (1900, c. 1976), Dewey anticipated the structure of inquiry, which he later related to education in the book How We Think (1910, c. 1978, revised in 1933, c. 1986). The latter essay, his four contributions to the book Studies in Logical Theory (1903, c. 1976), and six other essays published on logic were in the book Essays in Experimental Logic (1916). These essays cannot be found throughout his Collected Works (Boydston ed. 1969-1991) as each essay has been published under the year it was first published. which inquiry is done, taking into account that facts and ideas are related to each other. Ideas must be used to understand facts. It is in the process of trying to understand the world to which we belong that ideas are used. Ideas only create meaning if they are related to facts. This is how ideas are born. It is not a matter of getting the ideas first and then finding the facts. Ideas and facts develop together and together they constitute our knowledge about the world and tell us who we are in this world. A situation is never a single object or event or a set of objects and events.

For we never experience nor form judgements about objects and events in isolation, but only in connection with a contextual whole. This latter is what is called a 'situation'.

(Dewey 1938, c. 1949: 66).

The uncertain situation is open for inquiry in the sense that its constituting elements are at first unconnected. The clarified situation is the result of inquiry, and the situation closes for a while. In the interval between an uncertain and a clarified situation, we apply discourse by using symbols as means. We communicate with each other and ourselves when we experience an uncertain situation that we wish to or have to solve. These uncertain situations relate to everyday life. If we are driving and approach a crossroads, we must choose which road to take; a thicker example might be writing an article where we keep negotiating with ourselves and perhaps with others about what to include and exclude.

According to Dewey, science does not have access to other methods than the methods by which we orient ourselves in our everyday world. In both situations, the method of inquiry is used. The only way inquiry in everyday life differs from scientific inquiry is in terms of content. Everyday life inquiries deal with more practical situations. 
The inquiries are not primarily intellectual actions, and the solution is related to a specific context or group. Scientific inquiry is often of a more general nature.

Inquiry has a common structure or pattern regardless of whether it is used in everyday life or in science. Dewey describes inquiry as a process that starts with a sense that something is wrong. Intuitively, we suspect there is a problem. The suspicion does not necessarily arise from an intellectual wit. It is not until the inquirer(s) begin to define and formulate the problem that inquiry moves into an intellectual field by using the human ability to reason and think verbally. In other words, the inquirer(s) use their previous experiences from similar situations. According to Dewey, the inquirer(s) try to solve the problem by applying different working hypotheses and conclude by testing a model of solution. The initial feeling of uncertainty, the uncertainty that started the inquiry process must disappear before we can say the problem has been solved. If the inquiry is to lead to new experiences, it requires thoughts or reflection over the relation between the problem's definition and formulation and the solution. It is not until reflection has established a relation between the action and the consequence(s) of the action that learning takes place.

\section{The legacy of Dewey}

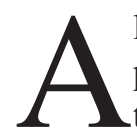
lready early in life, Dewey saw how philosophical thinking helped him to understand his experience of disintegration and separation. Hegel - and later Darwin's theory of evolution and the functional psychology's social orientation helped Dewey to understand that the world is a unity consisting of the conscious and intelligent activities of individual persons. Nothing in the world is outside or above human experience. The individual and the community cannot improve their ability to develop the world by turning to lofty and transcendental doctrines, but solely by acting and learning from experience, enabling them to act even more informed and wisely in future situations.

This personal realisation of unity founded in everyday life was the starting point for the development of Dewey's philosophical thinking and action. It is the basis for the experience-based concept of knowledge in pragmatism, and it is the background for Dewey's view on the importance of education. Dewey's concept of experience is a concept of transaction by which experience can simultaneously change persons and surroundings. Experience is not at root conscious or verbal, but it can be enhanced by conscious reflection. Dewey's concept of inquiry is directly linked to the pragmatic concept of knowledge and the concept of experience. Inquiry is a method to acquire experience, to construct knowledge. Inquiry is the method we use in everyday life, and at the same time the method can be applied in the construction of intended learning processes.

There is no contradiction between Dewey's thinking and the new social learning theories when they postulate that learning takes place as a result of participating in and across social communities of practice and that learning is enhanced by reflections over actions in, say, apprentice situations. For Dewey, learning is also a collective and lifelong phenomenon not confined to institutionalised educational environments. Dewey's contribution is first and foremost an understanding that connect philosophy and learning. His philosophy of reality, knowledge and actions, each in relation to each other, has left a clear mark on his educational thinking. Where new social learning theories emphasise participation in action and practice, Dewey stresses experience. Expe- 
rience includes active participation in practice as well as the subsequent consequences. But to turn this process into a learning experience, the learning subject must actively establish the connection, including the connection to his/her previous experiences. It means that Dewey underlines the importance of reflection or thinking, the cognitive field, much more than the social learning theories do. He sees thinking as simultaneously a result of reflection over experimental actions and an instrument for future actions. Thinking is, in Dewey's words "a distinctive experience", it is the "institutional endeavor to discover specific connections between something that we do and the consequences which result, so that the two become continuous" (Dewey 1916, c. 1966: 145).

Establishing thinking as an instrument for experimental action is captured in Dewey's concept of inquiry as the way in which people acquire knowledge. At the same time, it is a method for creating learning processes where active knowledge construction takes place. Dewey argues that we live an everyday life in which we learn, but also have the opportunity to create intended learning processes. He does not see the same contradiction between scholastic learning processes and learning processes through participation in practice, which is a feature of some new social learning theories. Dewey believes that the educational system can be used as a laboratory for inquiry and, thus, as a place for acquiring experiences. ${ }^{8}$

By means of his concept of experience, Dewey is also able to establish an actual relation between individual and social aspects. On the one side, experiences are always individual, but they derive from our common,

8 This does not prevent Dewey from being a harsh critic of the traditional schooling system; see e.g. Dewey 1899 , rev. 1915 , c. 1976. collective world of experience. Learning must be viewed as a relation between the individual and the social element - both the individual person and the community are participants in the learning processes. In the social learning theories, the individual tends to disappear as a category in favour of the social communities of practice. As a consequence, the learning subject disappears out of the picture. We might say that Dewey dissolves the artificial distinction between socialisation and learning as he regards the two concepts solely as analytic categories that can be used in a conceptual battle by institutions ready to make use of one or the other. There is no learning without socialisation and vice versa. Both activities take place in the established school and educational system and in everyday life.

\section{Conclusion}

$\mathrm{T}$ he purpose of this article is to point out how new social learning theories ran parallel to a long historical tradition within philosophical thinking and pedagogy. ${ }^{9}$ American pragmatism in general and John Dewey's understanding of knowledge and learning in particular are concrete examples to the extent they insist on a unity and interdependence between the collective society and the individual person and a philosophy of knowledge based on active inquiry and ever emergent experience.

I conclude by indicating how new social learning theories may learn from Dewey's anti-dualism. The issue is not a confrontation with the activity of thinking (or "cognition") in favour of action and practice, but an understanding of thinking as a tool for action and not as something elevated and outside the human world of experience. I

9 See also the very insightful article by Eric Bredo (1997) on this topic. 
Dewey's educational thinking as well as his educational practice, i.e., his Laboratory School, saw daylight around the 19th century turning into the 20th century. Dewey's model of everyday life was in many ways rural America, i.e., the American farm house as a model with all the everyday tasks around this to be learned (cooking, gardening, building a hut, etc.). The content of the Laboratory School did not reflect the approaching industrial age at the time. Given this background, one could for very good reasons question the relevance of Dewey's educational thinking for a knowledge society. Is Dewey still relevant apart from what I have already argued in terms of the relations between new social learning theories and Dewey's pragmatism and his concepts of experience and inquiry? If Dewey was not able to include the industrial society in his educational practice, how may the knowledge society be included?

I think that there are good reasons for Dewey again being relevant - and relevant to the knowledge society. A major reason is that computers are the prevailing tools in today's work. This makes it possible to re-unite work and school in a fairly easy and obvious way. The weaving together of computers and tele-communication creates a tool that is first and foremost guided by a certain kind of (exact programming-)language, which, in turn, can be used as a media for information access and for communication. This way of using computers is not very much different from using them in schools and in everyday life. Using computers as ways for creating learning experiences may, however, demand guidance, i.e., a teacher or tutor. The mere access to more information and communication does not ensure that the method of inquiry is learned and transactions occur.

The use of computers in work and education brings forward the issue of what action
10 See e. g. Lave's (op. cit.) seminal study on the (lack of) relation between school-learning and the everyday use of calculation skills. 
and thinking is when the tool is a computer. Schools and the educational system as a whole have an important role to play in creating situations for learning experiences to occur for learners. I.e., to point to how continuity between new forms of action (working on and with computers) may lead to new forms of thinking. A re-visit to Dewey's educational thinking may inspire teachers on all levels to do just that. A lot of work is, however, necessary to help point to a contemporary kind of continuity between action and thinking as well as its implications for learning in the knowledge society.

\section{A note on the work by and about John Dewey}

The Collected Works by John Dewey, and the Works about John Dewey (Levine, 1996) is available in book form and as CD-Roms. For Works about Dewey published later than 1995, there is a supplementary list on the URL address of the John Dewey Centre: http://www.siu.edu/ deweyctr/. The Collected Works by Dewey is published as Early Works (EW), Middle Works (MW), and Later Works (LW). EW covers the period from 1882-1898, and is published in 5 volumes; MW covers the period from 1899-1924, and is published in 15 volumes; and LW covers the period from $1925-1953$, and is published in 17 volumes. Besides the 37 volumes, an Index to the volumes is published as a separate book. The general editor of the Collected Work was $J o$ Ann Boydston, and Southern Illinois University Press (Carbondale and Edwardsville) published them between 1969-1991.

\section{Acknowledgements}

I would like to thank an anonymous reviewer for very helpful comments not only on content but also on language. I would also like to thank the John Dewey Centre for housing me for several periods during the fall of 1998, and for additional help via e-mail on many occasions.

\section{References}

Alexander, F. Matthias 1923: Constructive Conscious Control of the Individual. New York: Dutton. Dewey's preface has been republished in Boydston, Jo Ann (ed.) 1983: Middle Works 15. Carbondale \& Edwardsville: Southern Illinois University Press.

Bernstein, Richard J. (ed.) 1960: John Dewey. On Experience, Nature and Freedom. Representative Selections. New York: The Liberal Arts Press.

Bredo, Eric 1997: "The Social Construction of Learning", in Phye, Gary (ed.) Handbook of Academic Learning. Construction of Knowledge. San Diego: Academic Press: 3-43.

Brown, John S., Collins, Allan \& Duguid, Paul 1989: "Situated Cognition and the Culture of Learning”. Educational Researcher, 18(1): 32-42.

Burke, Tom 1994: Dewey's New Logic. A Reply to Russell. Chicago: The University of Chicago Press.

Childs, John L. 1956: American Pragmatism and Education. An Interpretation and Criticism. New York: Henry Holt and Company.

Dewey, Jane M. 1939, c. 1951: "Biography of John Dewey", in Schilpp, Paul Arthur (ed.) The Philosophy of John Dewey. New York: Tudor Publishing Company: 3-45.

Dewey, John 1890A, c. 1969: "Is Logic a Dualistic Science?" in Boydston, Jo Ann (ed.) 1983: Early Works 3. Carbondale \& Edwardsville: Southern Illinois University Press: 75-82. 
Dewey, John 1890B, c. 1969: "The Logic of Verification", in Boydston, Jo Ann (ed.) 1983: Early Works 3. Carbondale \& Edwardsville: Southern Illinois University Press: 83-89.

Dewey, John 1891, c. 1969: "The Present Position of Logical Theory", in Boydston, Jo Ann (ed.) 1983: Early Works 3. Carbondale \& Edwardsville: Southern Illinois University Press: 125-141.

Dewey, John 1899, rev. 1915, c. 1976: The School and Society. This essay can be found in Boydston, Jo Ann (ed.) 1976: Middle Works 1. Carbondale \& Edwardsville: Southern Illinois University Press: 1-109.

Dewey, John 1900, c. 1976: "Some Stages of Logical Thought", in Boydston, Jo Ann (ed.) 1983: Middle Works 1. Carbondale \& Edwardsville: Southern Illinois University Press: 151-174.

Dewey, John 1903, c. 1976: Studies in Logical Theory. Chicago: The University of Chicago Press. Dewey's 4 essays can be found in Boydston, Jo Ann (ed.) 1983: Middle Works 2. Carbondale \& Edwardsville: Southern Illinois University Press: 293-367.

Dewey, John 1905, c. 1981: "The Postulate of Immediate Empiricism", in McDermott, John J. 1973, c. 1981: The Philosophy of John Dewey. Chicago: University of Chicago Press: 240-248.

Dewey, John 1910, c. 1978: How We Think. Boston: D. C. Heath and Co. This version can be found in Boydston, Jo Ann (ed.) 1983: Middle Works 6. Carbondale \& Edwardsville: Southern Illinois University Press: 177-356.

Dewey, John 1916, c. 1966: Democracy and Education. An Introduction to the Philosophy of Education. New York: The Free Press.

Dewey, John 1916: Essays in Experimental Logic. Chicago: The University of Chicago Press.

Dewey, John 1920, c. 1936: Reconstruction in Philosophy. New York: Henry Holt and Company.

Dewey, John 1925, c. 1958: Experience and Nature. New York: Dover Publications.

Dewey, John 1930, c. 1960: "From Absolutism to Experimentalism", in Bernstein, Richard J. (ed.) 1960: John Dewey. On Experience,
Nature and Freedom. Representative Selections. New York: The Liberal Arts Press: 3-18.

Dewey, John 1931, c. 1981: "The Development of American Pragmatism", in McDermott, John J. (ed.) 1973, c. 1981: The philosophy of John Dewey. Chicago: University of Chicago Press: 41-58.

Dewey, John 1933, c. 1986: How We Think: A Restatement of the Relation of Reflective Thinking to the Educative Process. Boston: D. C. Heath and Company. This version can be found in Boydston, Jo Ann (ed.) 1983: Later Works 8. Carbondale \& Edwardsville: Southern Illinois University Press: 105-352.

Dewey, John 1934, c. 1958: Art as Experience. New York: Capricorn Books.

Dewey, John 1938, c. 1949: Logic. The Theory of Inquiry. New York: Henry Holt and Company.

Dewey, John 1938, c. 1963: Experience and Education. New York: Collier Books.

Dewey, John 1949, c. 1991: Knowing and the Known. With Arthur F. Bentley. Boston: The Beacon Press. This book can be found in Boydston, Jo Ann (ed.) 1991: Later Works 16. Carbondale \& Edwardsville: Southern Illinois University Press: 1-294.

Dreier, Ole 1999: "Personal Trajectories of Participation across Contexts of Social Practice". Outlines, 1: 5-32.

Dworkin, Martin S. 1959: Dewey on Education. Selections. New York: Teachers College.

Dykhuizen, George 1973: The Life and Mind of John Dewey. Carbondale and Edwardsville: Southern Illinois University Press.

Eastman, Max 1945, c. 1959: "John Dewey: My Teacher and Friend", in Eastman, Max Great Companions. New York: Farrar, Straus \& Cudahy: 249-298.

Fink, Hans 1969: John Dewey. Copenhagen: Berlingske Forlag.

Garforth, F.W. 1966: John Dewey. Selected Educational Writings. London: Heinemann.

Haskins, Casey \& Seiple, David I. (eds.) 1999: Dewey Reconfigured. Essays on Deweyan Pragmatism. Albany: State University of New York Press.

Hendley, Brian P. 1986: "John Dewey and the Laboratory School", in Hendley, Brian P. 
Dewey, Russell, Whitehead. Philosophers as Educators. Carbondale and Edwardsville: Southern Illinois Press: 14-138.

Illeris, Knud, Laursen, Per Fibæk \& Simonsen, Birgitte 1978: Samfundet og padagogikken. (Society and Pedagogics). Copenhagen: Munksgaard.

Illeris, Knus 1999: Laring - aktuel laeringsteori $i$ spandingsfeltet mellem Piaget, Freud og Marx. (Learning - topical learning theory in the field between Piaget, Freud and Marx). Roskilde: Roskilde Universitets Forlag.

Lave, Jean \& Wenger, Etienne 1991: Situated Learning. Legitimate Peripheral Participation. Cambridge: Cambridge University Press.

Lave, Jean 1988: Cognition in Practice. Mind, Mathematics and Culture in Everyday Life. Cambridge: Cambridge University Press.

Levine, Barbara (ed.) 1996: Works about John Dewey 1886-1995. Carbondale and Edwardsville: Southern Illinois Press.

Løvlie, Lars 1989: "Erfaring som handling" (Experience as Action), in Thuen, Harald \& Vaage, Sveinung (eds.) Oppdragelse til det moderne (Education to modern life). Oslo: Universitetsforlaget: 147-178.

Lundgren, Ulf P. 1989: "Pedagogik och psykologi. Om John Deweys filosofi” (Pedagogics and Psychology. On John Dewey's Philosophy), in Thuen, Harald \& Vaage, Sveinung (eds.) Oppdragelse til det moderne (Education to modern life). Oslo: Universitetsforlaget: 121-146.

McDermott, John J. 1973, c. 1981: The philosophy of John Dewey. Chicago: University of Chicago Press.

Nielsen, Klaus \& Kvale, Steinar (eds.) 1999: Mesterlare. Laring som social praksis. (Apprenticeship. Learning as social practice). Copenhagen: Hans Reitzels Forlag.

Rorty, Richard 1979, c. 1980: Philosophy and the Mirror of Nature. Princeton: Princeton University Press.

Rorty, Richard 1982: Consequences of Pragmatism. Minneapolis: University of Minnesota Press.

Salomon, Gavriel (ed.) 1993: Distributed Cognition. Psychological and Educational Con- siderations. Cambridge: Cambridge University Press.

Scheffler, Israel 1974, c. 1986: Four Pragmatists. A Critical Introduction to Peirce, James, Mead, and Dewey. London, New York: Routledge \& Paul.

Schön, Donald A. 1983: The Reflective Prac-titioner. How Professionals Think in Action. New York: Basic Books.

Schön, Donald A. 1987: Educating the Reflective Practitioner: Toward a New Design for Teaching and Learning in the Professions. New York: Basic Books.

Shusterman, Richard 1994, c. 1999: "Dewey on Experience: Foundation or Reconstruction?", in Haskins, Casey \& Seiple, David I. (eds.): Dewey Reconfigured. Essays on Deweyan Pragmatism. Albany: State University of New York Press: 193-219.

Sleeper, R. W. 1986: The Necessity of Pragmatism. John Dewey's Conception of Philosophy. New Haven and London: Yale University Press.

Stuhr, John J. (ed.) 1993: Philosophy and the Reconstruction of Culture. Pragmatic Essays after Dewey. Albany: State University of New York Press.

Tanner, Laurel N. 1997: Dewey's Laboratory School. Lessons for Today. New York: Teachers College Press.

Wenger, Etienne 1998: Communities of Practice. Learning, Meaning, and Identity. Cambridge: Cambridge University Press.

Westbrook, Robert B. 1991: John Dewey and American Democracy. Ithaca, N.Y.: Cornell University Press.

Winther-Jensen, Thyge 1989: Undervisning og Menneskesyn belyst gennem studier af Platon, Comenius, Rousseau og Dewey: En Antropologisk Betragtningsmåde. (The Education and Philosophy of Man through Studies of Plato, Comenius, Rousseau and Dewey: An Anthropological Approach). Copenhagen: Akademisk Forlag.

Østerlund, Carsten S. 1996: Learning Across Contexts. A field study of salespeople's learning at work. Psykologisk Skriftserie. (21)1. Aarhus: Aarhus University. 
outlines-2000. qxd 23-11-00 12:55 Side 102

102

Bente Elkjaer: The Continuity of Action and Thinking in Learning 